\title{
BIOCHAR FROM MAIZE HYBRID FERMENTATION RESIDUE - LOW COST AND EFFICIENT HEAVY METALS SORBENT
}

\author{
BIOWEGIEL Z POFERMENTACYJNEJ POZOSTAŁOŚCI KUKURYDZY \\ HYBRYDOWEJ - TANI I WYDAJNY SORBENT METALI CIĘŻKICH
}

\begin{abstract}
Biochar produced from fermentation residue of maize hybrid was used in untreated form as a sorbent for the removal of $\mathrm{Cd}(\mathrm{II}), \mathrm{Pb}(\mathrm{II})$ and $\mathrm{Zn}$ (II) from aqueous solution. The capability of biochar to immobilized ions was investigated by leaching test. Equilibrium between biochar sample and studied elements in solution was reached at a contact time $30 \mathrm{~min}$ for $\mathrm{Zn}$ (II) and $90 \mathrm{~min}$ for $\mathrm{Pb}$ (II) and $\mathrm{Cd}$ (II). The experimental data were described by pseudofirst-order and pseudo-second-order kinetic model, two- and three-parameter isotherms in non-linear form. The maximum sorption capacity achieved was $30.07 \mathrm{mg} \cdot \mathrm{g}^{-1}$ in the case of Cd(II) ions, $99.44 \mathrm{mg} \cdot \mathrm{g}^{-1}$ in the case of $\mathrm{Pb}$ (II) and 40.18 in the case of $\mathrm{Zn}$ (II). Biochar developed for this study is comparable to conventional biochar, low cost, non-toxic and experimental results show that is a suitable and efficient sorbent for $\mathrm{Cd}$ (II), $\mathrm{Pb}$ (II) and $\mathrm{Zn}$ (II) removal from aqueous solutions.
\end{abstract}

Keywords: biochar, adsorption characteristic, kinetics, heavy metals, non-linear isotherm

\section{Introduction}

Biosorption is an effective technological process employing low-cost materials derived from biomass for the removal of heavy metal ions from aqueous solutions. Biosorbents are easily available, environmentally friendly and are capable of binding pollutants in the active positions inside the structure of biosorbent $[1,2]$.

Although great effort is directed toward eliminating pollutants from wastewater, water pollution is still one of the most important environmental problems. Heavy metals are, in the view of their persistence, biomagnification and toxicity, one of the most important pollutants. The main sources of heavy metal contamination are e.g. alloy industries, metal plating, mining operation, pesticides, agricultural activities, smelting or batteries

\footnotetext{
${ }^{1}$ Nanotechnology Centre, VŠB-Technical University of Ostrava, 17. listopadu 15/2172, 70833 Ostrava-Poruba, Czech Republic, phone +420 597321 549, email: jana.seidlerova@vsb.cz

${ }^{2}$ ENET - Energy Units for Utilization of Non-Traditional Energy Sources, VŠB - Technical University of Ostrava, 17. listopadu 15/2172, 708 33, Ostrava-Poruba, Czech Republic, phone +420 597321559 , email: oldrich.motyka@vsb.cz

${ }^{3}$ Department of Nanobiotechnology, Biology Centre, ISB, CAS, Na Sadkach 7, 37005 Ceske Budejovice, Czech Republic, phone +420 387775 627, email: safarikova@nh.cas.cz

*Corresponding author: Michaela.tokarcikova@vsb.cz
} 
manufacture [3, 4]. Lead, cadmium and zinc are one of the most toxic and carcinogenic heavy metals that could cause serious environmental and health problems even at low concentrations $[4,5]$.

There are several technics to treat metal polluted wastewaters, for example chemical precipitation, ion exchange, reverse osmosis, membrane separation or electrolysis [4]. However, adsorption is fast, low-cost and relatively easy to realization.

Biochar is a fine-grained charred material originating from various organic materials under special conditions such as low temperatures and limited presence of oxygen [6]. It is a renewable source of fixed carbon - a possible alternative to other sources of char that are produced from fossil fuels such as coal and petroleum products [7]. The preparation temperature and kind of biomass used determines the main properties of biochar, mainly its homogeneity, which is, generally, very low. The thermal treatment of raw biosorbent leads to the formation of new pores and to a significant increase in specific area and sorption capacity [2]. However, it should be mentioned that biochar treated at lower temperatures shows lower adsorption capacity in comparison with biochar treated at high temperatures. The benefits of the material treated at higher temperatures are mainly greater surface area and high microporosity [8]. The high-temperature treatment of biomass can be, from an agricultural perspective, beneficial due to the reduction of pesticide residues in crops but harmful in the case of reducing the efficiency of herbicides. Therefore, compromise is to be reached between the increase of the sorption capacity at high pyrolysis temperature preparation of biochar and the advantages provided by its low-temperature preparation - in terms of reduced toxicity and adsorption $[8,9]$.

Biochar is studied for its ability to enhance the nutrient level of soils, its positive effect on the plant growth and it is applied as a sorbent in various applications for toxic materials removal [7, 10]. Biochar has been prepared e.g. from rice husks, olive pomace, orange waste, sewage sludge and compost [11]. The biochar maximum sorption capacity prepared from rapeseed was found to be $31.6 \mathrm{mg} \cdot \mathrm{g}^{-1}$ for $\mathrm{Cd}$ sorption and $83.5 \mathrm{mg} \cdot \mathrm{g}^{-1}$ for $\mathrm{Pb}$ [12]. When the papaya seed was used for the preparation, the maximum sorption capacity for $\mathrm{Pb}$ was $63.2-82.5 \mathrm{mg} \cdot \mathrm{g}^{-1}$ [4]. Other experimental studies confirm that biochar can efficiently remove heavy metal ions such as $\mathrm{Pb}^{2+}, \mathrm{Cu}^{2+}, \mathrm{Ni}^{2+}, \mathrm{Cd}^{2+}$ or $\mathrm{Zn}^{2+}$ from aqueous solution with the initial $\mathrm{pH}$ of solution 5-6 [5, 11].

The study of Beesley and Marmiroli [6] proved that biochar is an effective adsorbent and its application leads to reduction of high concentrations of soluble $\mathrm{Cd}$ and $\mathrm{Zn}$ in contaminated soil.

In comparison to the conventional methods used in industrial applications, adsorption is a fast, affordable and universal method of water purification and recycling. Industrial applications are often restricted by their high cost and other disadvantages such as incomplete removal, low selectivity, lengthiness of the process, high-energy consumption, and generation of toxic sludge, which is hard to eliminate [4].

Both the rate of the adsorption and the dynamic behaviour of the system are very important factors in the sorption process. Adsorption of adsorbates from the aqueous solutions includes three steps: the first step is the transport of the adsorbate from the bulk phase towards the surface of the adsorbent, the second step is the transport of adsorbate into the adsorbent by pore diffusion or surface diffusion (intraparticular diffusion) and the third step is the actual adsorption on the adsorbent surface. The slowest step of the adsorption process determines the adsorption rate [8]. 
The sorption mechanism is influenced by the physical and chemical characteristics of biochar and, therefore, sorption kinetics shows a strong dependence on these properties [8]. $\mathrm{Cd}(\mathrm{II}), \mathrm{Pb}(\mathrm{II})$ and $\mathrm{Zn}(\mathrm{II})$ ions with the initial concentrations of $10 \mathrm{mg} \cdot \mathrm{dm}^{-3}$ were selected for the kinetic studies. The effect of contact time necessary for their removal from aqueous solutions was observed.

Important information on the suitability of the use of adsorbents is provided adsorption isotherms. The isotherm equilibrium models applicable to adsorption processes can be used to describe affinity between adsorbents and adsorbates and to determine the bond energy and adsorption capacity. Most commonly used isotherms are the Freundlich and Langmuir adsorption isotherm as well as their combination (such as the Langmuir-Freundlich adsorption isotherm). Sorption isotherms have shown to be suitable for characterization of short-term and monocomponent adsorption of metal ions by different materials in aqueous solutions $[13,14]$.

Adsorption equilibrium data are important for description and understanding of the adsorption processes. Experimental data can be described by several adsorption models; therefore, using a correct adsorption model is very important. However, the fact that the experimental data fit the adsorption isotherms does not necessarily mean that the particular theoretical adsorption model is appropriate. Nevertheless, the calculated adsorption parameters can help explain the underlying mechanisms controlling the adsorption process and can predict the realistic parameter values.

This study deals with the adsorption of $\mathrm{Pb}(\mathrm{II}), \mathrm{Cd}(\mathrm{II})$ and $\mathrm{Zn}$ (II) ions from aqueous solution using biochar. The experimental sorption data were modelled according to the Freundlich, Langmuir, Temkin and Redlich-Peterson adsorption isotherms in non-linear form, using software ADStat.

\section{Materials and methods}

\section{Characterization of prepared biochar}

Biochar $(\mathrm{BCH})$ used in this study originated from fermentation residue of maize hybrid. The fermentation residue was dewatered, preheated at $80{ }^{\circ} \mathrm{C}$ for 2 hours and heated at $200-400{ }^{\circ} \mathrm{C}$. The biochar passed all biotoxicity tests, limits of heavy metals, and PAHs; dioxins and furans and the overall economy of its potential use is most interesting due to the possibility of its direct preparation at the place of its application (Council Decision) [15]. Quality of the prepared biochar is comparable to conventional biochar made from other lignocelluloses sources. Both the aforementioned characteristics and biochar preparation are described in more details in the article of [16].

The biochar was ball milled in FRITSCH pulverisette to obtain biochar particles with their size ranging from 200 to $90 \mu \mathrm{m}$. The total carbon content was analysed by MULTI NIC 3100 with furnace HT 1300 Analytika Jena.

\section{$X$-ray fluorescence}

The chemical composition of $\mathrm{BCH}$ was determined using energy dispersive fluorescence spectrometer (XRFS) SPECTRO XEPOS (SPECTRO Analytical Instruments $\mathrm{GmbH}$ ) equipped with $50 \mathrm{~W} \mathrm{Pd} \mathrm{X}$-ray tube. The samples were prepared in the form of pressed tablets (wax was used as a binder) for this measurement. 


\section{Infrared spectroscopy}

The sample in the form of pellets with $\mathrm{KBr}$ was measured ( $\mathrm{KBr}$ was added to $1.5 \mathrm{mg}$ of sample to the final weight of $300 \mathrm{mg}$ ) using Perkin Elmer 2000 FT-IR spectrometer. Infrared (IR) spectra were recorded in mid-IR region $4000-400 \mathrm{~cm}^{-1}$.

\section{Scanning electron microscopy}

The morphology of BCH sample was observed using Philips XL-30. The sample was coated with Au film and the SEM images were taken by a secondary electron detector.

\section{Specific surface area}

The specific surface area was measured with the Sorptomatic 1990 using nitrogen and calculated by the Advance Data Processing software according to the BET isotherm.

\section{Adsorption experiment}

$\mathrm{Cd}\left(\mathrm{NO}_{3}\right)_{2} \cdot 4 \mathrm{H}_{2} \mathrm{O}$ (SIGMA-ALDRICH, p.a. $\geq 99.0 \%$ ), $\mathrm{Pb}\left(\mathrm{NO}_{3}\right)_{2}$ (LACHEMA, p.a.) and $\mathrm{Zn}\left(\mathrm{NO}_{3}\right)_{2} \cdot 6 \mathrm{H}_{2} \mathrm{O}$ (SIGMA-ALDRICH, p.a. $\geq 99.0 \%$ ) were used to prepare aqueous solutions with $\mathrm{Cd}(\mathrm{II}), \mathrm{Pb}(\mathrm{II})$ or $\mathrm{Zn}(\mathrm{II})$ ions, respectively. Solutions were prepared using deionized water, the initial $\mathrm{pH}$ was 5.0-6.6.

\section{Kinetic and adsorption tests}

Batch sorption experiments were carried out in plastic flasks at laboratory temperature. $0.2 \pm 0.01 \mathrm{~g}$ of biochar sample with $0.05 \mathrm{dm}^{3}$ of solution containing $\mathrm{Cd}(\mathrm{II}), \mathrm{Pb}$ (II) or $\mathrm{Zn}$ (II) ions (the initial concentrations of $10 \mathrm{mg} \cdot \mathrm{dm}^{-3}$ ) were shaken at a constant speed $(4.5 \mathrm{rpm}$ ) in different time intervals to determine the optimal contact time. After shaking, the mixture was filtered through $0.45 \mu \mathrm{m}$ pore filter (Whatman). Concentrations of $\mathrm{Cd}(\mathrm{II}), \mathrm{Pb}$ (II) and $\mathrm{Zn}$ (II) ions in the filtrate were determined by atomic emission spectrometer with inductively coupled plasma (AES-ICP) Spectro Ciros Vision.

The differences between the initial and final concentrations of adsorbates were used to calculate the amount of adsorbed metal ions. Each experiment was repeated in parallel and averaged values are given as the results. The obtained data were used to calculate the equilibrium metal uptake capacity according to [17]:

$$
q=\frac{V\left(c_{0}-c_{r}\right)}{m}
$$

where $q\left[\mathrm{mg} \cdot \mathrm{g}^{-1}\right]$ is the amount of contaminant removed from solution, $c_{0}$ and $c_{r}$ are the concentrations of the metal ions in the initial solution and at the equilibrium after the sorption experiment $\left[\mathrm{mg} \cdot \mathrm{dm}^{-3}\right]$ in the aqueous solution, $V$ is volume of the solution $\left[\mathrm{dm}^{3}\right]$ and $m$ is the sorbent dose $[\mathrm{g}]$ in the mixture.

The kinetics and dynamics of adsorption of $\mathrm{Cd}(\mathrm{II}), \mathrm{Pb}(\mathrm{II})$ and $\mathrm{Zn}(\mathrm{II})$ on the $\mathrm{BCH}$ sample have been investigated by applying the pseudo-first-order kinetic model according to [8]:

$$
\log \left(q_{e}-q\right)=\log \left(q_{e}\right)-\frac{k_{1} \cdot t}{2.303}
$$

and pseudo-second-order kinetics model is defined [18]: 


$$
\frac{t}{q_{t}}=\frac{1}{k_{2} \cdot q_{e}^{2}}-\frac{t}{q_{e}}
$$

where $k_{1}$ is the pseudo-first-order rate constant $\left[\mathrm{dm}^{3} \cdot \mathrm{min}^{-1}\right], k_{2}$ is the adsorption rate constant of the pseudo-second-order kinetic model $\left[\mathrm{g} \cdot \mathrm{mg}^{-1} \cdot \mathrm{min}^{-1}\right]$.

Weber intraparticle diffusion model is expressed as following equation [19]:

$$
q_{t}=K_{i} \cdot t^{\frac{1}{2}}+C
$$

where $K_{i}$ is the intraparticle diffusion rate constant $\left[\mathrm{mg} \cdot \mathrm{g}^{-1} \cdot \mathrm{min}^{-0.5}\right]$ and $C$ is the intercept. For the intercept $C$, McKay et al. [20] have indicated that "extrapolation of the linear portion of the plot back to the axis provides intercepts which are proportional to the extent of the boundary layer thickness, that is, the larger the intercept the greater the boundary layer effect". According to Weber and Morris [19], if the intraparticle diffusion is a rate-limiting step, a plot $q_{t}$ vs $t^{0.5}$ should yield a straight line passing through the origin. Value of $C$ close to zero indicates that diffusion is the controlling step of the adsorption process [21].

\section{Sorption isotherms}

The two or three-parameter adsorption isotherms were used to describe the experimental adsorption data of metal ions (the Freundlich, Langmuir, Temkin and Redlich-Peterson adsorption isotherms). The experimental data were processed by non-linear determination.

\section{Freundlich isotherm model}

The Freundlich adsorption isotherm expression is shown in [22]:

$$
q_{e}=K_{F} \cdot c_{e}^{1 / n}
$$

where $K_{F}$ is capacity of adsorbent $\left[\mathrm{mg} \cdot \mathrm{g}^{-1}\right], n$ is constant expressing the intensity of adsorption. Adsorption isotherm is called favourable if $n>1$. If $n<1$, the cohesion forces are stronger than the forces between molecules of adsorbate. For $n=1$ the shape of adsorption isotherm is linear [23].

\section{Langmuir isotherm model}

The Langmuir adsorption isotherm can be expressed as [24]:

$$
q_{e}=\frac{q_{m} \cdot b \cdot c_{e}}{1+b \cdot c_{e}}
$$

where $q_{e}\left[\mathrm{mg} \cdot \mathrm{g}^{-1}\right]$ is the equilibrium amount of ion adsorbed per unit weight of adsorbent, $c_{e}\left[\mathrm{mg} \cdot \mathrm{dm}^{-3}\right]$ is the concentration of ion remaining in solution at equilibrium, $q_{m}$ is the amount of ion adsorbed per unit weight of adsorbent forming a complete monolayer on the surface $\left[\mathrm{mg} \cdot \mathrm{g}^{-1}\right]$ and $\mathrm{b}$ is a constant related to the energy [23].

$R_{L}$ is the separation factor determining whether an adsorption system is favourable or unfavourable. $R_{L}$ can be expressed as follows [17]:

$$
R_{L}=\frac{1}{1+b c_{m}}
$$


where $b$ is the Langmuir constant $\left[\mathrm{dm}^{3} \cdot \mathrm{mg}^{-1}\right]$ and $c_{m}$ is the maximum initial concentration of adsorbed ions $\left[\mathrm{mg} \cdot \mathrm{dm}^{-3}\right] . R_{L}=0$ characterizes irreversible adsorption, $0<R_{L}<1$ signifies favorable adsorption, $R_{L}=1$ shows linear adsorption and $R_{L}>1$ indicates unfavorable adsorption [17].

\section{Temkin isotherm}

The Temkin adsorption isotherm contains a constant corresponding to the adsorbate-adsorbent interaction and is expressed by [25]:

$$
q_{e}=\frac{R T}{b_{T}} \ln \left(K_{T} \cdot c_{e}\right)
$$

where $K_{T}$ is equilibrium binding constant $\left[\mathrm{dm}^{3} \cdot \mathrm{g}^{-1}\right], b_{T}\left[\mathrm{~J} \cdot \mathrm{mol}^{-1}\right]$ is the Temkin isotherm constant related to the adsorption heat of adsorption.

\section{Redlich Peterson isotherm}

The Redlich-Peterson adsorption model represents adsorption equilibrium over a wide concentration range, and for its versatility can be applied in both homogeneous and heterogeneous systems [26]. Redlich-Peterson isotherm is represented in:

$$
q_{e}=\frac{A \cdot c_{e}}{1+B \cdot c_{e}^{\beta}}
$$

where $A$ and $B$ are the Redlich-Peterson's parameters $\left[\mathrm{dm}^{3} \cdot \mathrm{mg}^{-1}\right], \quad \beta$ is the Redlich-Peterson's exponent reflecting the heterogeneity of the adsorbent and lies between $0-1$. The Redlich-Peterson isotherm converges to the Henry law for $\beta=0$ and to the Langmuir form if $\beta=1$ [27]. Mechanism of adsorption is hybrid and does not follow ideal monolayer adsorption [26].

\section{Results and discussion}

\section{Material characteristic}

The $\mathrm{BCH}$ sample (size $90-200 \mu \mathrm{m}$ ) contains $805 \mathrm{~g} \cdot \mathrm{kg}^{-1}$ of carbon. The chemical composition of $\mathrm{BCH}$ expressed in oxides is presented in Table 1.

Table 1

Chemical composition of biochar; LOI - lost on ignition

\begin{tabular}{|c|c|c|c|c|c|c|c|c|c|c|c|}
\hline Oxides & $\mathbf{N a}_{2} \mathbf{O}$ & $\mathbf{M g O}$ & $\mathbf{A l}_{2} \mathbf{O}_{3}$ & $\mathbf{S i O}_{\mathbf{2}}$ & $\mathbf{P}_{\mathbf{2}} \mathbf{O}_{\mathbf{5}}$ & $\mathbf{K}_{\mathbf{2}} \mathbf{O}$ & $\mathbf{C a O}$ & $\mathbf{T i O}_{\mathbf{2}}$ & $\mathbf{M n O}$ & $\mathbf{F e}_{2} \mathbf{O}_{3}$ & $\mathbf{L O I}$ \\
\hline [wt.\% $\%$ & 0.878 & 2.663 & 0.351 & 6.202 & 2.688 & 4.848 & 3.187 & 0.014 & 0.040 & 0.350 & 77.78 \\
\hline
\end{tabular}

\section{Infrared spectroscopy}

Figure 1 represents IR spectrum of BCH sample. The FT-IR spectrum had intensive band near $3392 \mathrm{~cm}^{-1}, 1593 \mathrm{~cm}^{-1}$ and $1098 \mathrm{~cm}^{-1}$, generally attributed to O-H stretching, aromatic $\mathrm{C}=\mathrm{C}$ ring stretching and aliphatic ether $\mathrm{C}-\mathrm{O}$ and alcohol $\mathrm{C}-\mathrm{OH}$ stretching [28]. A wide band at $3600-3200 \mathrm{~cm}^{-1}$ with the maximum at $3392 \mathrm{~cm}^{-1}$ could be assigned to $\mathrm{O}-\mathrm{H}$ stretching vibration, although mineral based $\mathrm{Si}-\mathrm{OH}$ could be expected as well [29, 30]. 


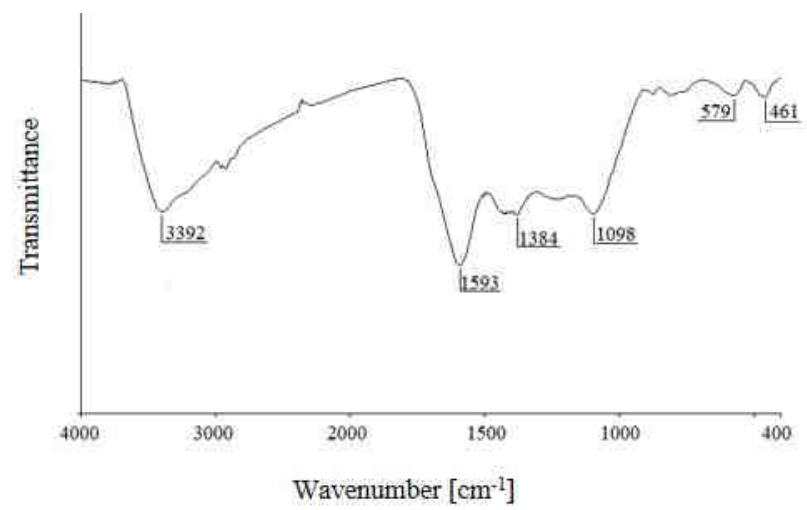

Fig. 1. FT-IR spectrum of BCH sample

\section{Scanning electron microscopy}

The scanning electron images of $\mathrm{BCH}$ are shown in Figure 2. Images and EDAX indicate low homogeneity of $\mathrm{BCH}$ sample. The number within image indicates the area in the sample that was analysed by EDX. The EDX spectrum shows the distribution of carbon, silicon, potassium, calcium and other minor elements in BCH (Fig. 2).

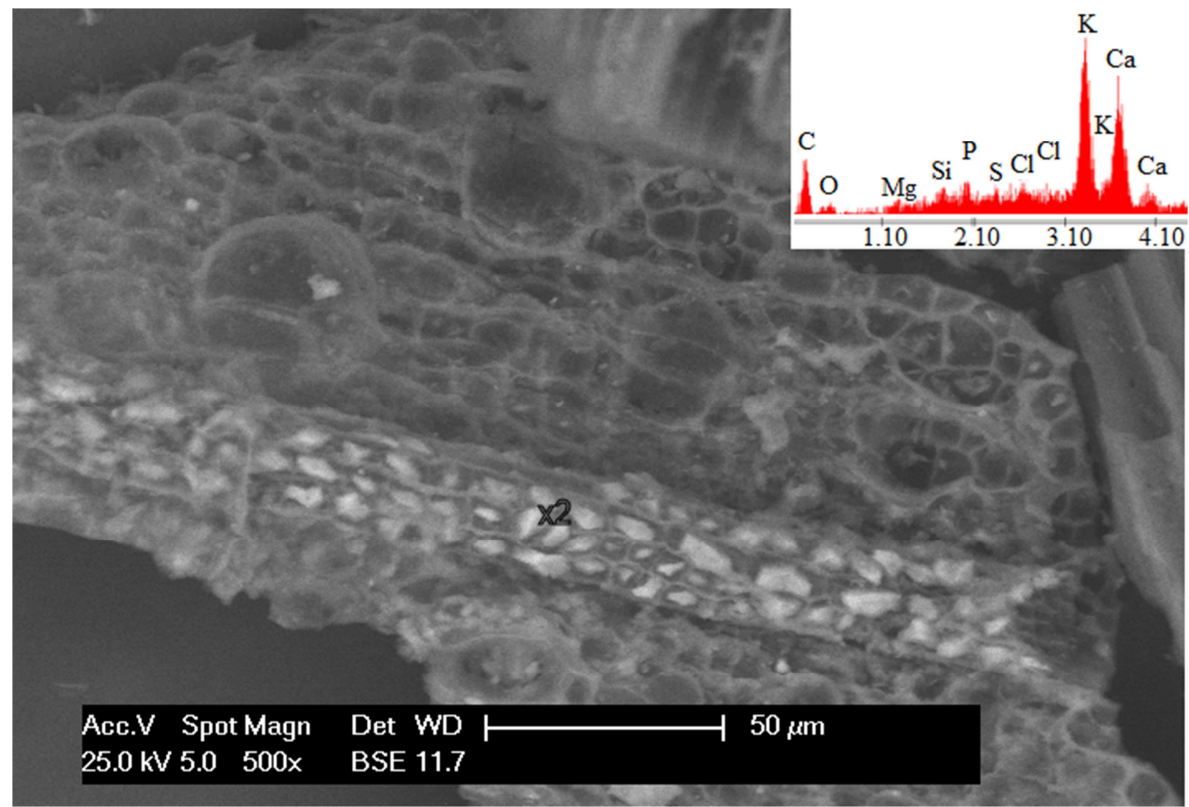

Fig. 2. Scanning electron image and EDAX of BCH, 500x 


\section{BET analysis}

BET analysis found that the specific surface area is $3.65 \mathrm{~m}^{2} \cdot \mathrm{g}^{-1}$ and value of monolayer volume is $0.8397 \mathrm{~cm}^{3} \cdot \mathrm{g}^{-1}$. It was proved that $\mathrm{BCH}$ is a microporous material.

\section{Effect of contact time}

Figure 3 illustrates the effect of contact time on adsorption of metals ions from solution. The initial concentration of metal ions in solution was $10 \mathrm{mg} \cdot \mathrm{dm}^{-3}$. Equilibrium was reached at contact time $90 \mathrm{~min}$ for $\mathrm{Pb}$ (II) and $\mathrm{Cd}(\mathrm{II})$ and $30 \mathrm{~min}$ for $\mathrm{Zn}$ (II).

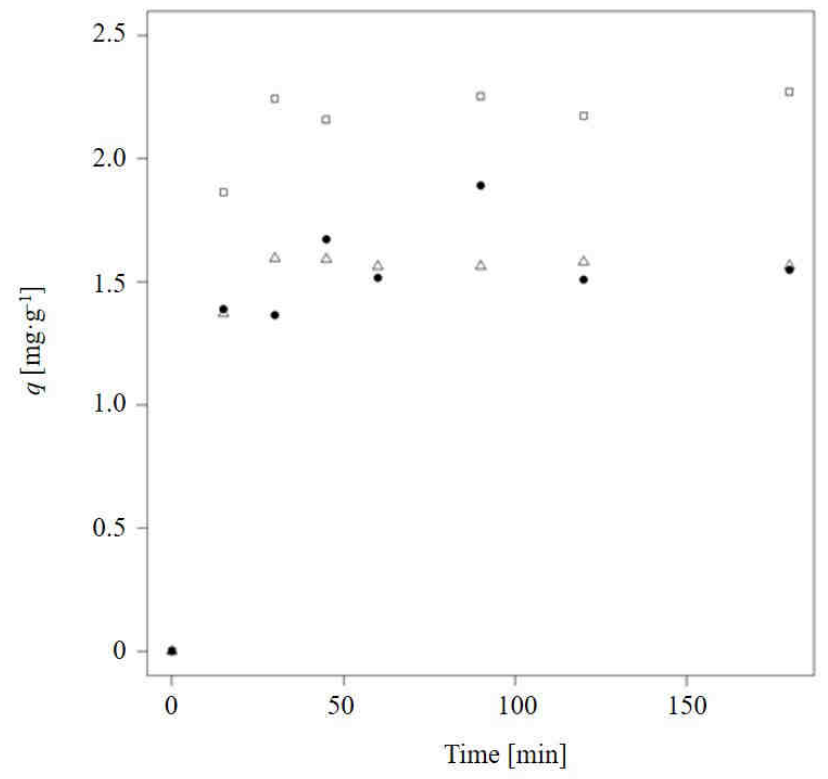

Fig. 3. The effect of contact time on adsorption of $\mathrm{Cd}(\mathrm{II}), \mathrm{Pb}(\mathrm{II})$ and $\mathrm{Zn}$ (II) ions onto $\mathrm{BCH}$ sample; $\bullet \mathrm{Cd}$, $\square \mathrm{Pb}, \Delta \mathrm{Zn}$

\section{Sorption kinetics}

The pseudo-first-order, pseudo-second-order and intraparticle diffusion model were used to establish the adsorption kinetic parameters. The previously mentioned parameters were determined by linear fitting procedure and are presented in Table 2.

The values of coefficients of determination $\left(R^{2}\right)$ are very similar for both kinetic models. Only $\mathrm{Cd}(\mathrm{II})$ and $\mathrm{Pb}(\mathrm{II})$ ions have the coefficient of determination higher than 0.9 . Considering the $R^{2}$ values, a better fit was achieved when the pseudo-second-order model was used (Fig. 4). Calculated kinetic constants show that the adsorption rate of $\mathrm{Pb}$ (II) ions is higher than adsorption rate of $\mathrm{Cd}(\mathrm{II})$ and $\mathrm{Zn}(\mathrm{II})$ ions. 
Parameters of pseudo-first-order, pseudo-second-order and intraparticle diffusion model for $\mathrm{Cd}(\mathrm{II}), \mathrm{Pb}$ (II) and $\mathrm{Zn}(\mathrm{II})$

\begin{tabular}{|c|c|c|c|c|}
\hline & & $\mathbf{C d}(\mathbf{I I})$ & $\mathbf{P b}(\mathbf{I I})$ & $\mathbf{Z n}(\mathbf{I I})$ \\
\hline \multirow{2}{*}{ Pseudo-first-order } & $k_{1}\left[\mathrm{dm}^{3} \cdot \mathrm{min}^{-1}\right]$ & 0.001 & 0.007 & 0.002 \\
\cline { 2 - 5 } & $R^{2}$ & 0.932 & 0.941 & 0.726 \\
\hline \multirow{2}{*}{ Pseudo-second-order } & $k_{2}\left[\mathrm{~g} \cdot \mathrm{mg}^{-1} \cdot \mathrm{min}^{-1}\right]$ & 180.6 & 13.88 & 124.6 \\
\cline { 2 - 5 } & $R^{2}$ & 0.940 & 0.941 & 0.750 \\
\hline \multirow{3}{*}{ Intraparticle diffusion } & $K_{i}\left[\mathrm{mg} \cdot \mathrm{g}^{-1} \cdot \mathrm{min}^{0.5}\right]$ & 0.051 & 0.237 & 0.044 \\
\cline { 2 - 5 } & $R^{2}$ & 0.466 & 1.000 & 0.976 \\
\cline { 2 - 5 } & $C$ & 1.173 & 0.946 & 1.109 \\
\hline
\end{tabular}

a)

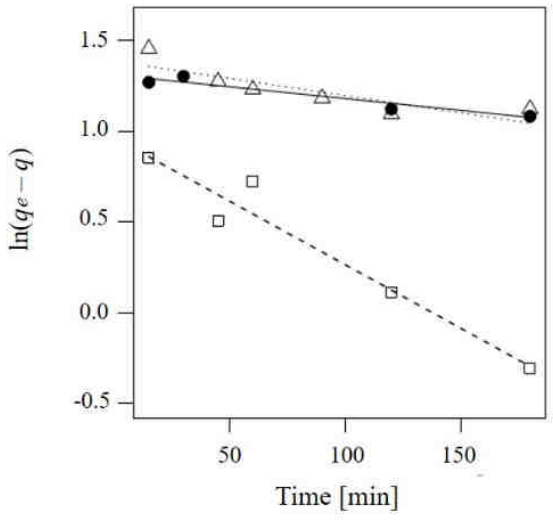

b)

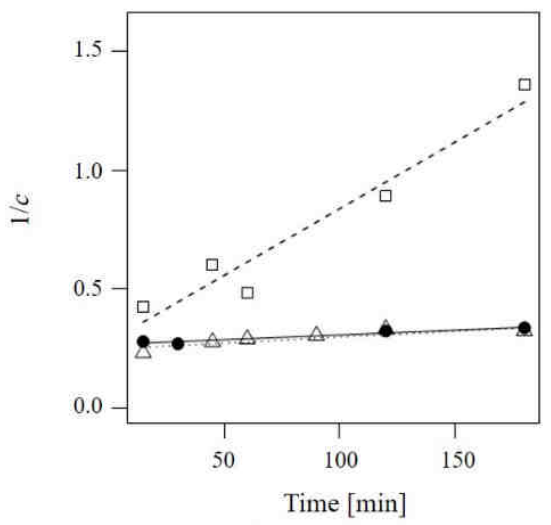

Fig. 4. a) Pseudo-first-order and b) pseudo-second-order kinetic model plots for the sorption of Cd(II), $\mathrm{Pb}$ (II) and $\mathrm{Zn}$ (II) ions on biochar sample; $\bullet \mathrm{Cd}$, $\square \mathrm{Pb}, \Delta \mathrm{Zn}$

Figure 5 shows the intraparticle diffusion model for the sorption of $\mathrm{Cd}(\mathrm{II}), \mathrm{Pb}(\mathrm{II})$ and $\mathrm{Zn}$ (II). Intraparticle diffusion is the rate controlling step if the slope of the individual line of the plot passes through the origin [31]. Two-line sections are apparent in Figure 5. The first section $\left(4<t^{0.5}<10\right)$ corresponds to the intraparticle diffusion. The second section $\left(10<t^{0.5}<14\right)$ is attributed to the diffusion of $\mathrm{Pb}(\mathrm{II}), \mathrm{Zn}(\mathrm{II})$ and $\mathrm{Cd}(\mathrm{II})$ through smaller pores, which is followed by the establishment of equilibrium. The influence of intraparticle diffusion is not apparent in these cases. Since the slope of the plot line did not pass through the origin, the intraparticle diffusion cannot be deemed a fully operational mechanism.

The intraparticle diffusion rate constant $K_{i}$ is higher for $\mathrm{Pb}(\mathrm{II})$ followed by $\mathrm{Zn}(\mathrm{II})$ and $\mathrm{Cd}(\mathrm{II})$ ions (see Table 2) which can be related to their respective ionic radius. The ionic radii are: $\mathrm{Pb}$ (II) $0.119 \mathrm{~nm}$ [32] > Cd(II) $0.095 \mathrm{~nm}$ [33] > Zn(II) $0.074 \mathrm{~nm}$ [34], therefore, the $\mathrm{Pb}$ (II) saturated the surface of sorbent faster than $\mathrm{Cd}(\mathrm{II})$ or $\mathrm{Zn}$ (II) ions. A low coefficient of determination $\left(R^{2}<0.77\right)$ does not suggest a significant relationship between $q$ and $t^{0.5}$ for the adsorption of $\mathrm{Cd}(\mathrm{II})$ and $\mathrm{Pb}(\mathrm{II})$ ions onto the biochar.

The intercept $C \neq 0$ (see Table 2) suggests that intraparticle diffusion was not the ratelimiting step [35]. Therefore, the limiting step in the present case is probably controlled by an external diffusion mechanism [36]. 


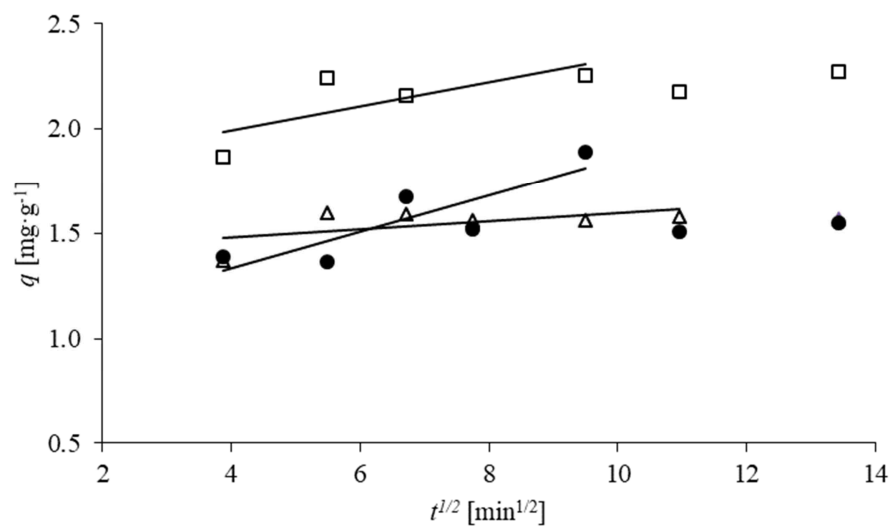

Fig. 5. The intraparticle diffusion model plots for the sorption of $\mathrm{Cd}(\mathrm{II}), \mathrm{Pb}(\mathrm{II})$ and $\mathrm{Zn}$ (II) ions on biochar sample; $\bullet \mathrm{Cd}, \square \mathrm{Pb}, \Delta \mathrm{Zn}$
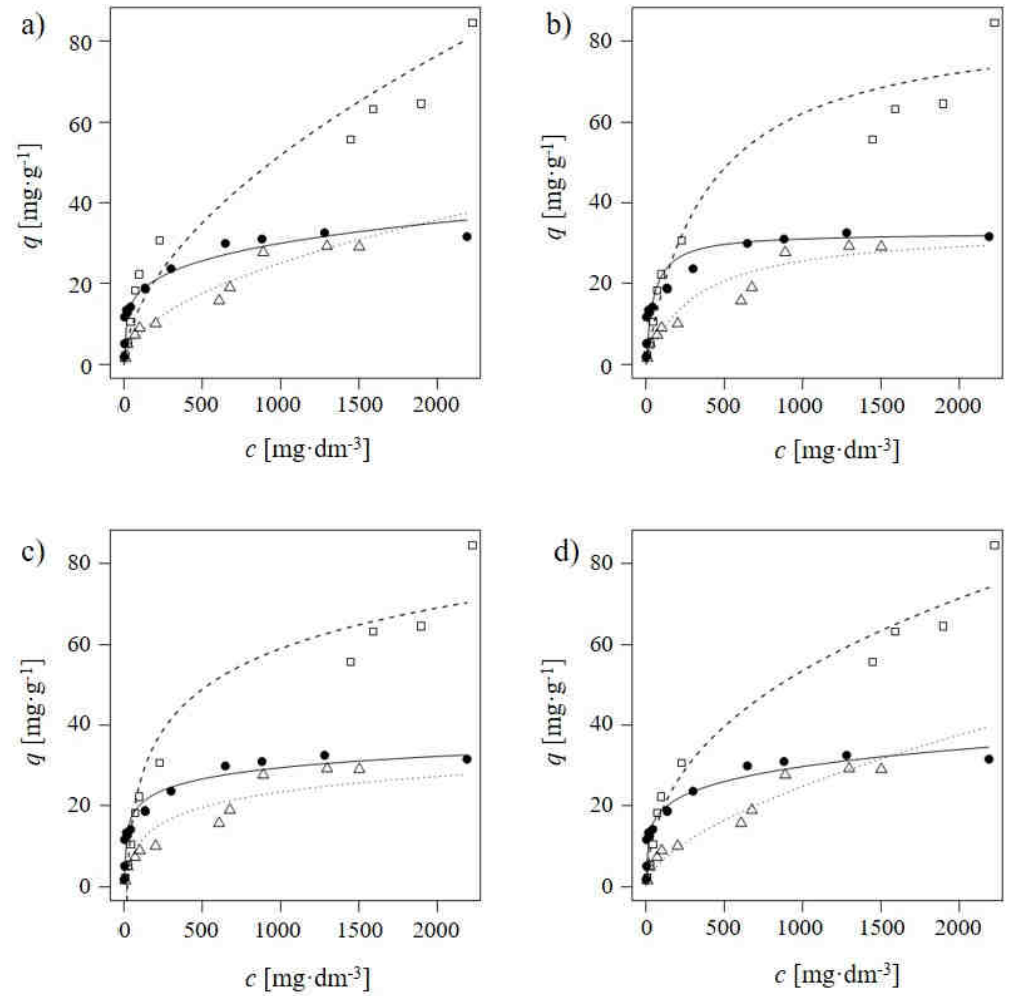

Fig. 6. Experimental adsorption data and a) Freundlich, b) Langmuir, c) Temkin, d) Redlich-Peterson adsorption model of $\mathrm{Cd}(\mathrm{II}), \mathrm{Pb}$ (II) and $\mathrm{Zn}$ (II) ions adsorbed on $\mathrm{BCH}$; $\bullet \mathrm{Cd}, \square \mathrm{Pb}, \Delta \mathrm{Zn}$ 


\section{Adsorption test of $\mathrm{Cd}, \mathrm{Pb}$ and $\mathrm{Zn}$ ions onto biochar}

The sorption process was tested at various initial concentration of metal ions (10-2500 $\mathrm{mg} \cdot \mathrm{dm}^{-3}$ for $\mathrm{Pb}(\mathrm{II}), 10-1500 \mathrm{mg} \cdot \mathrm{dm}^{-3}$ for $\mathrm{Zn}(\mathrm{II}), 10-2000 \mathrm{mg} \cdot \mathrm{dm}^{-3}$ for $\mathrm{Cd}(\mathrm{II})$ ) and at $25{ }^{\circ} \mathrm{C}$ and $\mathrm{pH} 5-6.6$. The $\mathrm{pH}$ values of sorption solutions were not adjusted; therefore, the initial $\mathrm{pH}$ values were influenced by the concentration of the monitored ions.

The experimental data and modelled adsorption isotherms of $\mathrm{Cd}(\mathrm{II}), \mathrm{Pb}$ (II) and $\mathrm{Zn}$ (II) ions are shown in Figure 6.

The sorption data of $\mathrm{Cd}(\mathrm{II}), \mathrm{Pb}(\mathrm{II})$ and $\mathrm{Zn}(\mathrm{II})$ ions on $\mathrm{BCH}$ sample were analysed using Freundlich (Eq. (5)), Langmuir (Eq. (6)), Temkin (Eq. (8)) and Redlich-Peterson isotherm models (Eq. (9)). The isotherms constants for sorption of metal ions onto the $\mathrm{BCH}$ sample are presented in Table 3.

Parameters from the fitting of the Freundlich, Langmuir, Temkin and Redlich-Peterson equations for $\mathrm{Cd}(\mathrm{II}), \mathrm{Pb}$ (II) and $\mathrm{Zn}$ (II) sorption

\begin{tabular}{|c|c|c|c|c|}
\hline \multirow{2}{*}{$\begin{array}{c}\text { Isotherm } \\
\text { model }\end{array}$} & \multirow{2}{*}{$\begin{array}{c}\begin{array}{c}\text { Calculated } \\
\text { parameters }\end{array} \\
{[\text { pts] }} \\
\end{array}$} & \multicolumn{3}{|c|}{ Adsorbate } \\
\hline & & $\operatorname{Cd}(\mathrm{II})$ & $\mathbf{P b}(\mathrm{II})$ & $\overline{Z n(I I)}$ \\
\hline \multirow{6}{*}{ Freundlich } & $R^{2}$ & 0.943 & 0.975 & 0.958 \\
\hline & $K_{F}\left[\mathrm{mg} \cdot \mathrm{g}^{-1}\right]$ & 6.347 & 2.196 & 0.781 \\
\hline & $N$ & 4.447 & 2.184 & 1.997 \\
\hline & $A I C$ & 26.84 & 37.85 & 1.814 \\
\hline & $M E P$ & 9.684 & 33.58 & 6.171 \\
\hline & $R S S$ & 75.30 & 238.7 & 41.10 \\
\hline \multirow{7}{*}{ Langmuir } & $R^{2}$ & 0.864 & 0.954 & 0.924 \\
\hline & $q_{m}\left[\mathrm{mg} \cdot \mathrm{g}^{-1}\right]$ & 30.07 & 84.04 & 40.18 \\
\hline & $B$ & 0.034 & 0.003 & 0.002 \\
\hline & $A I C$ & 37.56 & 48.16 & 24.10 \\
\hline & $M E P$ & 18.35 & 47.84 & 10.88 \\
\hline & $R S S$ & 171.8 & 430.5 & 74.64 \\
\hline & $R_{L}$ & 0.474 & 0.814 & 0.944 \\
\hline \multirow{6}{*}{ Temkin } & $R^{2}$ & 0.947 & 0.944 & 0.868 \\
\hline & $b_{T}\left[\mathrm{~J} \cdot \mathrm{mol}^{-1}\right]$ & 605.0 & 167.7 & 442.0 \\
\hline & $K_{T}\left[\mathrm{dm}^{3} \cdot \mathrm{g}^{-1}\right]$ & 1.488 & 0.006 & 0.076 \\
\hline & $A I C$ & 25.27 & 46.56 & 29.60 \\
\hline & $M E P$ & 7.265 & 79.59 & 20.83 \\
\hline & $R S S$ & 66.79 & 526.9 & 129.4 \\
\hline \multirow{7}{*}{$\begin{array}{l}\text { Redlich- } \\
\text { Peterson }\end{array}$} & $R^{2}$ & 0.955 & 0.976 & 0.946 \\
\hline & $A\left[\mathrm{dm}^{3} \cdot \mathrm{g}^{-1}\right]$ & 6.888 & 0.942 & 126.0 \\
\hline & $\mathrm{B}\left[\mathrm{dm}^{3} \cdot \mathrm{g}^{-1}\right]$ & 0.843 & 0.241 & 306.2 \\
\hline & $B$ & 0.812 & 0.613 & 0.406 \\
\hline & $A I C$ & 25.25 & 39.22 & 22.60 \\
\hline & $M E P$ & 9.403 & 3.657 & 11.13 \\
\hline & $R S S$ & 57.15 & 225.4 & 52.61 \\
\hline
\end{tabular}

$R S S$ - residual sum of squares

To select the best model, the values of determination coefficient $\left(R^{2}\right)$, Akaike information criterion (AIC) and means quadratic error of prediction $(M E P)$ were used. The most suitable model is the model giving the lowest value of $A I C, M E P$ and the highest value of determination coefficient $R^{2}$ [37]. 
The determination coefficients of $\mathrm{Cd}(\mathrm{II}), \mathrm{Pb}(\mathrm{II})$ and $\mathrm{Zn}$ (II) ions adsorption for all applied isotherms are higher than 0.9, except for $\mathrm{Cd}(\mathrm{II})$ ions in case of the Langmuir isotherm and $\mathrm{Zn}(\mathrm{II})$ ions in case of Temkin isotherm. All isotherm models show only a little differences between their calculated determination coefficients.

Parameters determined from the Freundlich sorption isotherm provide valuable physical information about metal sorption onto biochar. The Freundlich adsorption constant was the highest for the sorption of $\mathrm{Pb}$ (II) and $\mathrm{Cd}(\mathrm{II})$ (see Table 3). The relatively high value of the Freundlich constant enables easy sorption of $\mathrm{Cd}(\mathrm{II})$ and $\mathrm{Pb}$ (II) ions on the sorbent. The Freundlich parameter $n$ as a criterion of metal sorption intensity is the highest for Cd(II) ions sorption $\left(n_{F}=4.45\right)$ [35]. The value of $n>1$ indicates that sorption intensity is favourable at high concentrations [26]. The lowest value of $A I C$ and $M E P$ and relatively high coefficients of determination make the Freundlich isotherm model the most suitable model for the description of sorption of $\mathrm{Pb}(\mathrm{II})$ and $\mathrm{Zn}$ (II) on biochar.

The values of the $q_{m}$ parameter calculated from the Langmuir isotherm were in the following order: $\mathrm{Pb}$ (II) $>\mathrm{Zn}(\mathrm{II})>\mathrm{Cd}(\mathrm{II})$. Sorption efficiency of the used material, expressed as Langmuir $q_{m}$ parameters, was compared with another biochar (Table 4). The tested biochar stands out as the best $\mathrm{Pb}$ (II) biosorbent with the largest $q_{m}$ parameter (99.4 $\left.\mathrm{mg} \cdot \mathrm{g}^{-1}\right)$. For $\mathrm{Cd}(\mathrm{II})$ and $\mathrm{Zn}(\mathrm{II})$ sorption, the biochar belongs to one of most efficient biosorbents.

Table 4

$\mathrm{Cd}(\mathrm{II}), \mathrm{Pb}(\mathrm{II})$ and $\mathrm{Zn}$ (II) sorption capacity $\left(q_{m}\right)$ of selected types of biochar

\begin{tabular}{|c|c|c|c|}
\hline & Biochar & Paragraph spacing $q_{m}\left[\mathrm{mg} \cdot \mathrm{g}^{-1}\right]$ & Reference \\
\hline \multirow{9}{*}{ Cd(II) } & Sida hermaphrodita & 32.57 & [39] \\
\hline & Wheatstraw & 35.71 & [39] \\
\hline & Oak wood char & 0.37 & [40] \\
\hline & Pine bark char & 0.34 & [40] \\
\hline & Oak bark char & 5.40 & [40] \\
\hline & Carbon F-400 & 8.0 & [40] \\
\hline & Spartina alterniflora & 33.90 & [41] \\
\hline & Active carbon & 12.64 & [41] \\
\hline & Fermentation residue of maize hybrid & 30.07 & Presented study \\
\hline \multirow{8}{*}{$\mathbf{P b}(\mathrm{II})$} & Pine wood char & 4.13 & {$[40]$} \\
\hline & Oak wood char & 2.62 & [40] \\
\hline & Pine bark char & 3.00 & [40] \\
\hline & Oak bark char & 13.10 & [40] \\
\hline & Carbon F-400 & 30.11 & [40] \\
\hline & Spartina alterniflora & 37.80 & [41] \\
\hline & Active carbon & 29.20 & [41] \\
\hline & Fermentation residue of maize hybrid & 99.44 & Presented study \\
\hline \multirow{5}{*}{$\mathbf{Z n}(\mathbf{I I})$} & Sida hermaphrodita & 41.84 & [39] \\
\hline & Wheatstraw & 48.08 & [39] \\
\hline & Spartina alterniflora & 23.26 & [41] \\
\hline & Active carbon & 12.9 & [13] \\
\hline & Fermentation residue of maize hybrid & 40.18 & Presented study \\
\hline
\end{tabular}

The Langmuir affinity constant $(b)$ of ions could be put in the following order: $\mathrm{Cd}(\mathrm{II})>\mathrm{Pb}(\mathrm{II})>\mathrm{Zn}$ (II) which could mean that $\mathrm{Cd}$ (II) more easily bonded to the binding sites of biochar sample, then $\mathrm{Zn}$ (II) and $\mathrm{Pb}(\mathrm{II})$ follow [38]. The separation factor $\left(R_{L}\right)$ values demonstrate the higher affinity of $\mathrm{Cd}$ (II) ions to biochar compared to $\mathrm{Pb}$ (II) or $\mathrm{Zn}$ (II) 
ions. The separation factor $\left(0<R_{L}<1\right)$ indicates that the process of adsorption is favourable. However, compared to other sorption models, the Langmuir model has a limited application for adsorption of $\mathrm{Cd}(\mathrm{II})$ onto biochar considering the coefficient of determination $\left(R^{2}=0.864\right)$. This can be caused by the low homogeneity of the biochar sample.

The third two-parameter adsorption model - the Temkin isotherm can be considered the best of two-parameter models - compared to both the Freundlich and Langmuir isotherms. The calculated results show that the value of equilibrium binding constant of $\mathrm{Cd}(\mathrm{II})$ is $K_{T}=1.488 \mathrm{dm}^{3} \cdot \mathrm{g}^{-1}$. Values of the same constant for $\mathrm{Pb}$ (II) and $\mathrm{Zn}$ (II) are 0.006 and $0.076 \mathrm{dm}^{3} \cdot \mathrm{g}^{-1}$, respectively. The adsorption heat expressed by Temkin isotherm constant decreased in order $\mathrm{Cd}(\mathrm{II})>\mathrm{Zn}(\mathrm{II})>\mathrm{Pb}(\mathrm{II})$.

The Redlich-Peterson adsorption isotherm was the best model for describing experimental data. The calculated Redlich-Peterson coefficients differed substantially in all the studied metal ions. The highest values of adsorption coefficients were calculated for $\mathrm{Pb}$ (II), lower for $\mathrm{Zn}$ (II) and the lowest for adsorption of $\mathrm{Cd}(\mathrm{II})$ ions.

The Temkin and Redlich-Peterson isotherm model fitted experimental data of Cd(II) adsorption better than the ones of $\mathrm{Pb}$ (II) due to their relatively high coefficient of determination and low AIC, MEP and RSS. Both mentioned isotherms fitted the adsorption of $\mathrm{Zn}(\mathrm{II})$ ions, however, the statistical parameters were worse, e.g. the coefficient of determination was lower than 0.9 .

The heavy metal cations are probably bound by van der Waals forces on the biochar surface. The mechanism of sorption, desorption and recycling potential of biochar will be studied in the future.

\section{Conclusions}

Experimental adsorption data of $\mathrm{Cd}(\mathrm{II}), \mathrm{Pb}(\mathrm{II})$ and $\mathrm{Zn}(\mathrm{II})$ ions on biochar did not fit the same two- or three-parameter adsorption isotherms. The adsorption rates of all studied metal ions were described by the pseudo-second-order kinetic model. According to the diffusion study, the kinetics is not influenced by interparticle diffusion, but the limiting step is probably controlled by a diffusion mechanism and by the establishment of equilibrium. The values of the $q_{m}$ parameter calculated from the Langmuir isotherm were $84 \mathrm{mg} \cdot \mathrm{g}^{-1}$ for $\mathrm{Pb}(\mathrm{II}), 30.1 \mathrm{mg} \cdot \mathrm{g}^{-1}$ for $\mathrm{Cd}(\mathrm{II})$ and $40.2 \mathrm{mg} \cdot \mathrm{g}^{-1}$ for $\mathrm{Zn}(\mathrm{II})$ ions. The experimental results show that biochar used in this study is a suitable, low cost and efficient sorbent for Cd(II), $\mathrm{Pb}(\mathrm{II})$ and $\mathrm{Zn}$ (II) ions from aqueous solutions.

The greatest advantage of biochar application lies in the elimination of the waste material from biomass production and its subsequent utilization in sorption and degradation of pollutants in the environment. Biochar application has a great and long-term potential in many sectors of industry. The future research efforts should be focused on desorption processes, potential recycling of biochar and degradation of various other pollutants or their combination.

\section{Acknowledgements}

This work was supported by the project ID No. LO1404, ,Sustainable Development of ENET Center".

The work was supported by ERDF/ESF New Composite Materials for Environmental Applications (No. CZ.02.1.01/0.0/0.0/17_048/0007399). Authors also wish to thank 
J. Marousek for providing the biochar and all colleagues, who participated in the measurements.

\section{References}

[1] Ding W, Dong X, Ime IM, Gao B, Ma LQ. Chemosphere. 2014;105:68-74. DOI: 10.1016/j.chemosphere.2013.12.042.

[2] Valili S, Siavalas G, Karapanagioti HK, Manariotis ID, Christanis K. J Environ Manage. 2013;128:252-58. DOI: 10.1016/j.jenvman.2013.04.057.

[3] Vardhan KH, Kumar PS, Panda RC. J Mol Liq. 2019;290:111197. DOI: 10.1016/j.molliq.2019.111197.

[4] Yadav SK, Singh DK, Sinha S. J Environ Chem Eng. 2014;2:9-19. DOI: 10.1016/j.jece.2013.10.019.

[5] Inyang M, Gao B, Yao Y, Xue Y, Zimmerman AR, Pullammanappallil P, et al. Bioresour Technol. 2012;110:50-6. DOI: 10.1016/j.biortech.2012.01.072.

[6] Beesley L, Marmiroli L. Environ Pollut. 2011;159:474-80. DOI: 10.1016/j.envpol.2010.10.016.

[7] Peterson SC, Jackson MA. Ind Crop Prod. 2014;53:228-35. DOI: 10.1016/j.indcrop.2013.12.028.

[8] Ho YS, McKay G. Sorption of dye from aqueous solution by peat. Chem Eng J. 1998;70(2):115-24 DOI: 10.1016/S0923-0467(98)00076-1.

[9] Tang J, Zhu W, Kookana R, Katayama A. J Biosci Bioeng. 2013;116:653-59. DOI: 10.1016/j.jbiosc.2013.05.035.

[10] Trakal L, Komárek M, Száková J, Zemanová V, Tlustoš P. Plant Soil Environ. 2011;57:372-80. DOI: 10.17221/155/2011-PSE.

[11] Pellera F-M, Giannis A, Kalderis D, Anastasiadou K, Stegmann R, Wang J-Y, et al. J Environ Manage. 2012;96(1):35-42. DOI: 10.1016/j.jenvman.2011.10.010.

[12] Štefusová K, Lovás M, Zubrik A, Matik M, Václavíková M. Nova Biotechnologica et Chimica. 2012;11(2):139-46. DOI: 10.2478/v10296-012-0016-x.

[13] Oladoja NA, Aboluwoye CO, Oladimeji YB. Turkish J Eng Env Sci. 2008;32(5):303-12. Available from: http://journals.tubitak.gov.tr/engineering/issues/muh-08-32-5/muh-32-5-6-0806-8.pdf.

[14] Ijagbemi CHO, Baek M-H, Kim D-S. J Hazard Mater. 2009;166:538-46. DOI: 10.1016/j.jhazmat.2008.11.085.

[15] Council Decision 2003/33EC, Establishing criteria and procedures for the acceptance of waste at landfills pursuant to Article 16 of and Annex II to Directive 1999/31/EC, 2002. Available from: http://www.fao.org/faolex/results/details/en/c/LEX-FAOC039228.

[16] Maroušek J. Clean Techn Environ Policy. 2014;16:1821-5. DOI: 10.1007/s10098-014-0730-y.

[17] Corami A, Mignardi S, Ferrini V. J Colloid Interface Sci. 2008;317;402-8. DOI: 10.1016/j.jcis.2007.09.075.

[18] Blanchard G, Maunaye M, Martin G. Water Res. 1984;18:1501-7. DOI: 10.1016/0043-1354(84)90124-6

[19] Weber WJ, Morris JC. J Sanitary Eng Div American Society of Civil Engineers. 1963;89:31-60. DOI: 10.12691/env-1-1-1.

[20] McKay C, Otterburn MS, Sweeney AG. Water Res. 1980;14:21-7. DOI: 10.1016/0043-1354(80)90038-X.

[21] Oladoja NA, Aboluwoye CO, Oladimeji YB, Ashogbon AO, Otemuyiwa IO. Desalination. 2008;227:190-203. DOI: 10.1016/j.desal.2007.06.025.

[22] Freundlich HMF. J Phys Chem. 1906;57:385-470. DOI: 10.1515/zpch-1907-5723.

[23] Yousef RI, El-Eswed B, Al-Muhtaseb AH. Chem Eng J. 2011;171:1143-1149. DOI: 10.1016/j.cej.2011.05.012.

[24] Langmuir I. J Am Chem Soc. 1918;40:1361-403. DOI: 10.1021/ja02242a004

[25] Foo KY, Hameed BH. Chem Eng J. 2010;156:2-10. DOI: 10.1016/j.cej.2009.09.013.

[26] Gimbert F, Morin-Crini N, Renault R, Badot P-M, Crini G. J Hazard Mater. 2008;157:34-46. DOI: 10.1016/j.jhazmat.2007.12.072.

[27] Kumar KV, Monteiro de Castro M, Martinez-Escandell M, Molina-Sabio M, Silvestre-Albero J, Rodriguez-Reinoso F. Chem Phys Lett. 2010;492:187-92. DOI: 10.1016/j.cplett.2010.04.044.

[28] Wang CH, Tu Q, Dong D, Strong PJ, Wang H, Sun B, et al. J Hazard Mater. 2014;280:409-16. DOI: 10.1016/j.jhazmat.2014.08.030.

[29] Taha SM, Amer ME, Elmarsafy AE, Elkady MY. J Environ Chem Eng. 2014;2:2013-25. DOI: 10.1016/j.jece.2014.09.001.

[30] Chia CHH, Gong B, Joseph SD, Marjo CHE, Munroe P, Rich AM. Vib Spectrosc. 2012;62:248-57. DOI: 10.1016/j.vibspec.2012.06.006.

[31] Alvani SA, Hojati S, Landi A. Geoderma. 2019;350:19-28. DOI: 10.1016/j.geoderma.2019.05.004.

[32] Ullah Z, Atiq S, Naseem S. J Alloys Compd. 2013;555:263-7. DOI: 10.1016/j.jallcom.2012.12.061. 
[33] McGowan R, Vaughan T, Feng Q-R, Guo J, Xu X, Zhang I, et al. Solid State Commun. 1995;94:21-5. DOI: 10.1016/0038-1098(95)00019-4.

[34] Duvuru HB, Alla SK, Shaw SK, Meena SS, Gupta N, Prasad BBVSV, et al. Ceramic International. 2019;45:16512-20. DOI: 10.1016/j.ceramint.2019.05.185.

[35] Gupta S, Kumar D, Gaur JP. Chem Eng J. 2009;148:226-33. DOI: 10.1016/j.cej.2008.08.019.

[36] Zhang L, Li W, Cao H, Hu D, Chen X, Guan Y, et al. Bioresour Technol. 2019;291:121818. DOI: 10.1016/j.biortech.2019.121818.

[37] Meloun M, Militký J. Anal Chim Acta. 2001;439:169-91. DOI: 10.1016/S0003-2670(01)01040-6.

[38] Apiratikul R, Pavasant P. Bioresour Technol. 2008;99(8):2766-77. DOI: 10.1016/j.biortech.2007.06.036.

[39] Bogusz A, Oleszczuk P, Dobrowolski R. Bioresour Technol. 2015;196:540-9. DOI: 10.1016/j.biortech.2015.08.006.

[40] Mohan D, Pittman Jr.CHR, Bricka M, Smith F, Yancey B, Mohammad J, et al. J Colloid Interface Sci. 2007;310:57-73. DOI: 10.1016/j.jcis.2007.01.020.

[41] Kołodyńska D, Krukowska J, Thomas P. Chem Eng J. 2016;307:353-63. DOI: 10.1016/j.cej.2016.08.088. 